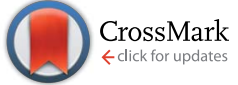

Cite this: RSC Adv., 2015, 5, 53047
Received 10th April 2015 Accepted 10th June 2015

DOI: $10.1039 / \mathrm{c} 5 \mathrm{ra06464c}$

www.rsc.org/advances

\section{Optimization and characterization of CLEAs of the very thermostable dimeric peroxidase from Roystonea regia†}

\author{
Alba Morales, $\ddagger^{\mathrm{a}}$ Oveimar Barbosa, $\ddagger^{\mathrm{b}}$ Nazzoly Rueda, ${ }^{\mathrm{ac}}$ Zayda Fonseca, ${ }^{\mathrm{a}}$ \\ Rodrigo Torres, $\S^{a}$ Rafael C. Rodrigues, ${ }^{d}$ Claudia Ortiz ${ }^{\star e}$ and Roberto Fernandez- \\ Lafuente*c
}

\begin{abstract}
This paper describes the optimization of the immobilization of the peroxidase from Roystonea regia (RPTP) using the technique of the crosslinking enzyme aggregates. The immobilization was optimized using response surface methodology and after evaluating three different precipitants, ethanol was finally selected. Three variables were analyzed, glutaraldehyde concentration, precipitant concentration and time before collecting the RPTP-CLEAs. The immobilization yield was around $75 \%$. The activity of the RPTP-CLEA was very high, this was even more patent at $\mathrm{pH}$ 3, where the free RPTP was fully inactive and the RPTP-CLEA maintained $40 \%$ of the maximum activity. In stress inactivations, the RPTP-CLEA maintained the very high thermostability that presented the free enzyme at $90{ }^{\circ} \mathrm{C}$ and $\mathrm{pH} 7$ (half-live of $50 \mathrm{~min}$ ). At pH 3, the free enzyme suffered subunit dissociation as a first step of the inactivation, this is not possible using RPTP-CLEAs and provided a very high thermostabilization (that depends on the enzyme concentration). The stability of the enzyme in the presence of hydrogen peroxide is good at low concentrations of this reagent (e.g., $10 \mathrm{mM}$ ), but if the concentration is higher (e.g., $300 \mathrm{mM}$ ), the enzyme stability drops. The immobilization provides an improved stability in the presence of this oxidant, but the values reached may not be high enough for some applications. The RPTP-CLEAs may be used for the decoloration of methyl orange solutions using $5 \mathrm{mM}$ of hydrogen peroxide for 4 cycles ( $4 \mathrm{~h}$ each cycle) without apparent decrease in activity (but only degrading around 50\% of the substrate). Using $225 \mathrm{mM}$ of this oxidative reagent, the activity slowly decreased after each cycle (but enabling the full destruction of the colorant). This immobilized enzyme may be used even at $\mathrm{pH} 3$ and $225 \mathrm{mM}$ hydrogen peroxide, conditions where the free enzyme is completely inactive.
\end{abstract}

\section{Introduction}

Peroxidases are ubiquitous oxidoreductases that use hydrogen peroxide or alkyl peroxides as oxidants. They may have different

${ }^{a}$ Escuela de Química, Grupo de Investigación en Bioquímica y Microbiología (GIBIM), Universidad Industrial de Santander, Edificio Camilo Torres 210, Bucaramanga, Colombia

${ }^{b}$ Departamento de Quimica, Facultad de Ciencias, Universidad del Tolima, Ibagué, Colombia

'Departamento de Biocatálisis, Instituto de Catálisis-CSIC, C/Marie Curie 2, Campus UAM-CSIC, Cantoblanco, 28049 Madrid, Spain. E-mail: rfl@icp.csic.es

${ }^{d}$ Biocatalysis and Enzyme Technology Lab, Institute of Food Science and Technology, Federal University of Rio Grande do Sul, Av. Bento Gonçalves, 9500, P.O. Box 15090, Porto Alegre, RS, Brazil

${ }^{e}$ Escuela de Bacteriología y Laboratorio Clinico, Universidad Industrial de Santander, Bucaramanga, Colombia.E-mail: ortizc@uis.edu.co

$\dagger$ Electronic supplementary information (ESI) available. See DOI: $10.1039 / \mathrm{c} 5 \mathrm{ra} 06464 \mathrm{c}$

$\$$ Both authors have evenly worked in this paper.

§ Current address: Laboratorio de Biotecnología, Instituto Colombiano del Petróleo-Ecopetrol, Piedecuesta, Bucaramanga, Colombia. uses as industrial biocatalysts. ${ }^{1}$ They may effectively catalyze selective oxidations of electron-rich substrates, which include the hydroxylation of arenes, the oxyfunctionalizations of phenols and aromatic amines, the epoxidation and halogenation of olefins, the oxygenation of heteroatoms and the enantioselective reduction of racemic hydroperoxides. ${ }^{2,3}$ They can also catalyze the oxidative polymerization of different compounds (e.g., phenols and aromatic amines). ${ }^{4}$ Peroxidase may be also of interest in contamination control, e.g., soil detoxification, or remediation of wastewater industrial dyes. ${ }^{5}$ Peroxidases have also found use in analytical systems in biosensors, as the determination of the hydrogen peroxide concentration linked to different oxidases. ${ }^{4}$

Hydrogen peroxide is a substrate of these enzymes, and this makes that the enzyme needs to be in contact with it, with the likely problems that this can generate in terms of enzyme stability. ${ }^{6}$ In many instances, the enzyme has been coupled to an oxidase to generate, in situ and in a continuous way, low amounts of this compound that could have a lower effect on enzyme stability. ${ }^{7-9}$ 
The peroxidase from royal palm (Roystonea regia) (RPTP) has special interest due to its reported extreme thermostability and resistance to acid conditions. It was first described in pure form in 2001, as an enzyme having a molecular weight of $51 \mathrm{kDa}$ and an isoelectric point of $3.5 .^{10}$ It is a dimeric enzyme very highly glycosylated (nine $N$-glycosylation sites) whose structure has been recently resolved. ${ }^{11,12}$ RPTP belongs to the family of class III secretory plant peroxidases and it contains one heme group and two calcium-binding sites in similar locations.

The structural stability of RPTP has been described to be $\mathrm{pH}$ dependent. ${ }^{13}$ At $\mathrm{pH} 3$, where ion pairs have disappeared due to protonation, the thermally induced denaturation of RPTP is irreversible and strongly dependent upon the scan rate, suggesting that this process is under kinetic control. Moreover, thermally induced transitions at this $\mathrm{pH}$ value are dependent on the protein concentration, allowing it to be concluded that in solution RPTP behaves as a dimer, which undergoes thermal denaturation coupled with dissociation. ${ }^{13}$ The authors proposed the dimeric nature of the enzyme as one of the main factors responsible for the unusually high stability of RPTP. However, this dimeric nature may become a problem when the enzyme is used as a biocatalyst; as enzyme dissociation of an immobilized enzyme may lead to their operational inactivation (via washing of the released subunits). ${ }^{\mathbf{1 4}}$

The enzyme has been used in diverse reactions, such oxidation of luminol, ${ }^{15}$ a conducting complex of polyaniline and poly(2-acrylamido-2-methyl-1-propanesulfonic acid). ${ }^{\mathbf{1 6}}$

In this paper, we have intended the immobilization of this highly stable enzyme for the first time in the literature. Due to their glycosylated (that may make complex an intense interaction with the surface of a support) and multimeric nature, we have decided to try the potential of the chemical crosslinking enzyme aggregates (CLEAs) proposed by Prof. Sheldon. ${ }^{17-20}$ This method has the advantage of not requiring the use of a support, being quite simple and having been described to be a good method to prevent dissociation of multimeric enzymes. ${ }^{21}$ The disadvantages are mainly related to diffusional problems (all the solid of the biocatalysts may be enzyme). ${ }^{22}$ Due to the complexity of the many variables that can have a relevant role in the final performance of the CLEA, ${ }^{23}$ we decided to use the strategy of experimental design following a response surface methodology, to detect any kind of likely covariance that could exist, using as main parameter the optimization the CLEA activity. ${ }^{24}$ This strategy has already shown the advantages in the design of CLEAs from other enzymes. ${ }^{25}$ The final features of the optimized CLEA will be analyzed in terms of stability/activity at different $\mathrm{pH}$ values, effect of enzyme concentration on stability, stability on the presence of hydrogen peroxide, finally the reuse of the CLEA in the decolourization of methyl orange will be presented.

\section{Materials and methods}

\subsection{Materials}

Leaves of royal palm tree (Roystonea regia) were harvested in the territory of the state of Santander, Colombia. Only green leaves were used. Hydrogen peroxide ( $30 \mathrm{wt} \%$ in $\mathrm{H}_{2} \mathrm{O}$ ), poly(ethylene glycol) (PEG) (MW 10 000) and ethanol were purchased from Merck. Guaiacol was from J. T. Baker. Glutaraldehyde and methyl orange were from Sigma-Aldrich. All reagents and solvents were of analytical grade.

\subsection{Extraction of peroxidase from royal palm (RPTP) leaves}

Peroxidase from royal palm leaves was extracted and partially purified as described by Sakharov et al. ${ }^{\mathbf{1 0}}$ (see Table 1-S and Fig. 1-S $\dagger$ ). The leaves of palm tree were washed with distilled water and milled. The samples obtained were divided in two equal portions. The first part was homogenized in $10 \mathrm{mM}$ buffer phosphate at pH $6.0\left(4 \mathrm{~mL} \mathrm{~g}^{-1}\right)$ and submitted to gentle stirring for 12 hours. The homogenate was filtered and used as extraction solution for the second portion, stirred for 12 hours, filtered and stored at $4{ }^{\circ} \mathrm{C}$. The pellet was discarded. To remove pigments, $\mathrm{PEG}$ and $\left(\mathrm{NH}_{4}\right)_{2} \mathrm{SO}_{4}$ were added to a concentration of $14 \%$ and $10 \%(\% \mathrm{w} / \mathrm{v})$, respectively, to the solution obtained. The solution was stirred until homogenization and held at $25{ }^{\circ} \mathrm{C}$ until the formation of two phases. The dark phase was separated and discarded. The eluted containing active peroxidase was concentrated using Amicons ultra centrifugal filters with low-binding Ultracel membranes of 30000 NMWL and centrifugation $\left(5000 \times g ; 15 \mathrm{~min} ; 4{ }^{\circ} \mathrm{C}\right)$. The fraction containing peroxidase activity was collected and stored at $4{ }^{\circ} \mathrm{C}$.

\subsection{Standard determination of enzyme activity}

This assay was performed by measuring the increase in absorbance at $470 \mathrm{~nm}$ produced by the release of tetraguaiacol in the oxidation of $18.2 \mathrm{mM}$ guaiacol in $10 \mathrm{mM}$ sodium phosphate at pH 6 and $25{ }^{\circ} \mathrm{C}$ ( $\varepsilon$ under these conditions is $5200 \mathrm{M}^{-1} \mathrm{~cm}^{-1}$ ) containing $2 \mathrm{mM}$ of hydrogen peroxide. To start the reaction, a volume of $20-100 \mu \mathrm{L}$ of peroxidase solution or suspension was added to $2.5 \mathrm{~mL}$ of substrate solution. One international unit of activity ( $\mathrm{U}$ ) was defined as the amount of enzyme that oxidases 1 $\mu$ mol of guaiacol per minute under the conditions previously described. Protein concentration was determined using Bradford's method ${ }^{26}$ and bovine serum albumin was used as the reference.

\subsection{Cross linked enzyme aggregates (CLEAs) preparation}

CLEAs were prepared according to Schoevaart et al. ${ }^{19}$ using ethanol, acetone or PEG for protein precipitation and glutaraldehyde as crosslinking agent. ${ }^{27}$ A volume of $3 \mathrm{~mL}$ of protein precipitant at different concentrations $(50,70$ or $90 \% \mathrm{v} / \mathrm{v})$ was added to $0.3 \mathrm{~mL}$ of peroxidase solution (RPTP, $0.5 \mathrm{mg} \mathrm{mL}^{-1}$ ) at $4{ }^{\circ} \mathrm{C}$ and constant stirring (magnetic stirring at $300 \mathrm{rpm}$ ). After 1 hour, glutaraldehyde was added to the desired concentration $(0.5,1.25$ or $2 \%(\mathrm{w} / \mathrm{v}))$ and the reaction mixture was incubated for 6,12 or $18 \mathrm{~h}$. CLEAs were centrifuged and recovered by centrifugation, washed with $25 \mathrm{mM}$ phosphate buffer, and finally stored at $4{ }^{\circ} \mathrm{C}$.

\subsection{CLEAs preparation experimental design}

A full factorial design $\left(3^{3}\right)$ with three variables varying at three levels was carried out in order to obtain the optimal conditions for 
CLEAs preparation. Precipitant concentration (50-70\% v/v), glutaraldehyde concentration $(0.5-2.0 \% \mathrm{w} / \mathrm{v})$ and reaction time (6-12 h) were evaluated. One experimental design was performed for each precipitant: ethanol, acetone and PEG. Table 1 shows the 27 experiments of each design. The runs were performed in a random order, but are presented in standard order in the tables.

\subsection{RPTP thermal inactivation experiments}

Solutions containing different concentrations of enzyme preparations were suspended in $10 \mathrm{mM}$ of sodium citrate at $\mathrm{pH} 3$ or sodium phosphate at $\mathrm{pH} 7$ at different temperatures. Periodically, samples were withdrawn and the activity was measured using guaiacol as indicated above. Half-lives were calculated from the observed inactivation courses.

\subsection{RPTP inactivation in the presence of hydrogen peroxide}

Enzyme preparations were suspended in $10 \mathrm{mM}$ of sodium citrate at $\mathrm{pH} 3$ or sodium phosphate at $\mathrm{pH} 6$ at different hydrogen peroxide concentrations $(10 \mathrm{mM}-1.2 \mathrm{M})$ at $25{ }^{\circ} \mathrm{C}$. Periodically, samples were withdrawn and the activity was measured using guaiacol. Half-lives were calculated from the observed inactivation courses.

\subsection{Operational stability}

Methyl orange was prepared in $50 \mathrm{mM}$ of sodium citrate at $\mathrm{pH} 3$ or sodium phosphate at $\mathrm{pH} 6$ to a final concentration of $45 \mu \mathrm{M}$, containing hydrogen peroxide at different concentrations $(5$ or $225 \mathrm{mM}$ ). 4.6 U of CLEAs were suspended on dye solution and gently stirred for 4 hours at $25{ }^{\circ} \mathrm{C}$. Spectrophotometrically dye degradation was scanned over a wavelength range of 250-650 $\mathrm{nm}$. Standard calibration curve was prepared at maximum wavelength and used for the estimation of dye concentration in aqueous phase. Once the reaction was completed, the CLEAs were recovered from the reaction suspension mixture, washed with distilled water and used again in a fresh methyl orange solution.

\section{Results}

\subsection{Optimization of the protocol of preparation of the peroxidase CLEAs}

Initially, for the preparation of peroxidase CLEAs, three precipitant agents were evaluated: ethanol, acetone and PEG (MW 10 000). Precipitant concentration, glutaraldehyde concentration and reaction time were tested, for each one of these precipitant agents, by an experimental design. The matrix of these experiments and the results for each precipitant agent is presented in Table 1. In general, preparations using ethanol

Table 1 Experimental design for CLEA preparation

\begin{tabular}{|c|c|c|c|c|c|c|}
\hline Run & $\begin{array}{l}\text { Precipitant concentration } \\
(\%)\end{array}$ & $\begin{array}{l}\text { Glutaraldehyde } \\
\text { concentration (\%) }\end{array}$ & $\begin{array}{l}\text { Reaction time } \\
\text { (h) }\end{array}$ & \multicolumn{3}{|c|}{ Specific activity $\left(\mathrm{U} \mathrm{mg}^{-1}\right)$} \\
\hline 2 & $-1(50)$ & $-1(0.5)$ & $0(12)$ & 61 & 36 & 512 \\
\hline 3 & $-1(50)$ & $-1(0.5)$ & $1(18)$ & 83 & 58 & 522 \\
\hline 4 & $-1(50)$ & $0(1.25)$ & $-1(6)$ & 61 & 61 & 568 \\
\hline 7 & $-1(50)$ & $1(2.0)$ & $-1(6)$ & 81 & 165 & 6 \\
\hline 8 & $-1(50)$ & $1(2.0)$ & $0(12)$ & 295 & 669 & 183 \\
\hline 9 & $-1(50)$ & $1(2.0)$ & $1(18)$ & 295 & 162 & 178 \\
\hline 10 & $0(70)$ & $-1(0.5)$ & $-1(6)$ & 1700 & 229 & 301 \\
\hline 11 & $0(70)$ & $-1(0.5)$ & $0(12)$ & 913 & 500 & 391 \\
\hline 12 & $0(70)$ & $-1(0.5)$ & $1(18)$ & 904 & 124 & 426 \\
\hline 17 & $0(70)$ & $1(2.0)$ & $0(12)$ & 600 & 59 & 90 \\
\hline 18 & $0(70)$ & $1(2.0)$ & $1(18)$ & 780 & 20 & 61 \\
\hline 19 & $1(90)$ & $-1(0.5)$ & $-1(6)$ & 1018 & 4 & 1301 \\
\hline 20 & $1(90)$ & $-1(0.5)$ & $0(12)$ & 1476 & 75 & 1355 \\
\hline 21 & $1(90)$ & $-1(0.5)$ & $1(18)$ & 502 & 40 & 1459 \\
\hline 22 & $1(90)$ & $0(1.25)$ & $-1(6)$ & 1948 & 91 & 1724 \\
\hline 23 & $1(90)$ & $0(1.25)$ & $0(12)$ & 1888 & 46 & 1997 \\
\hline 24 & $1(90)$ & $0(1.25)$ & $1(18)$ & 478 & 7 & 1863 \\
\hline 25 & $1(90)$ & $1(2.0)$ & $-1(6)$ & 459 & 117 & 11 \\
\hline 26 & $1(90)$ & $1(2.0)$ & $0(12)$ & 323 & 51 & 5 \\
\hline 27 & $1(90)$ & $1(2.0)$ & $1(18)$ & 449 & 19 & 8 \\
\hline
\end{tabular}

${ }^{a}$ Numbers in parenthesis are the real values for each variable. 


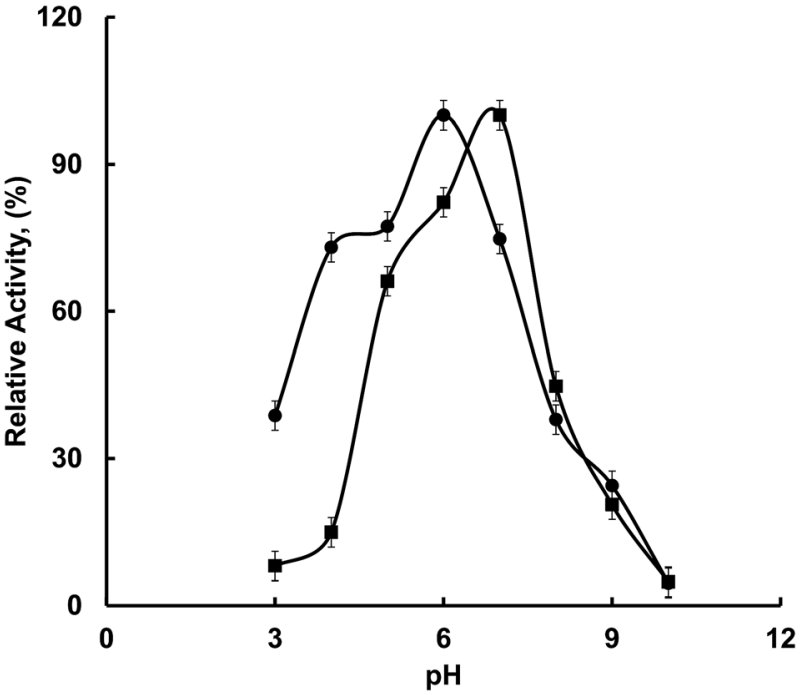

Fig. 1 Effect of $\mathrm{pH}$ on the guaiacol activity of different peroxidase preparations. Activity was determined as described in Section 2.100\% relative activity was the maximum activity for each preparation. Circles: CLEAs, squares: soluble RPTP.

and PEG presented good activity. The soluble enzyme, after extraction, has $910 \mathrm{U} \mathrm{mg}^{-1}$; the highest CLEAs activity was found using high concentrations of precipitant agent (70 or $90 \%$ ), where it was possible to obtain a specific activity twotimes higher than the soluble enzyme (runs 22 and 23). However, the immobilization yield (comparing initial enzyme units and final immobilized units) was around 75\% using ethanol. There are some likely explanations for this discrepancy. First, the yield may be not $100 \%$ just because some enzyme molecules may be not precipitated (we have detected around $7 \%$ of the RPTP activity in the supernatant) or because no all CLEAs were recovered (e.g., very small particles may be lost during elimination of the supernatants after centrifugation). Second, the specific activity using the free enzyme is based in an indirect determination of enzyme concentration, and that may give no a no-real protein concentration value, while CLEA is actually weighted. Moreover, even if the enzyme accounts for more than $50 \%$ of the total protein in the crude (see Fig. 1-S†), the enzyme may be partially purified during the immobilization if certain selectivity in the target protein precipitation is achieved. In any case, even although the comparison with the free enzyme may be unreliable, the comparison between CLEAs activities should be a real one. And a recovered activity of $75 \%$ considering the high diffusion problems of this kind of immobilization protocol may be considered very successful.

Using acetone, a color change was observed in the reaction medium, probably due to the formation of the Schiff's base, the reaction product between the $\varepsilon$-amino groups of Lys residues and the reactive groups of glutaraldehyde. ${ }^{28}$ The CLEAs prepared using acetone presented lower activity than the soluble enzyme. Thus, acetone was discarded as precipitant agent for preparation of peroxidase CLEAs.

The statistical analysis for the preparations using ethanol and PEG can be observed in the Pareto charts, at a significant level of 0.1 , presented in Fig. $2-\mathrm{S}$ and $3-\mathrm{S}, \uparrow$ respectively. Using ethanol as precipitant agent, among the main effects (linear effects) only the precipitant concentration was statistically significant, with a positive effect, which means that the higher the concentration, the higher the activity, as mentioned before. Using PEG, precipitant concentration and glutaraldehyde concentration were statistically significant, but with opposite effects. While precipitant concentration was positive, glutaraldehyde concentration was negative, i.e. increasing its concentration the CLEA activity decreased. The relationship between the variables is presented in the response surface plots in the Fig. 4-S and 5-S, $\dagger$ for ethanol and PEG, respectively. Observing the contour plots for ethanol as precipitant agent, it can be seen that the optimal conditions to prepare peroxidase CLEAs is ethanol concentration of $80 \%$, glutaraldehyde concentration of $1 \%$ and a reaction time of $12 \mathrm{~h}$. Whereas using PEG as precipitant agent, the optimal conditions were PEG concentration of $90 \%$, glutaraldehyde concentration of $0.9 \%$ and reaction time of $15 \mathrm{~h}$. In both cases, it was possible to obtain very high specific activities, higher than the soluble enzyme. ${ }^{29}$ However, due to the lower cost of ethanol and the slightly higher activity obtained using this precipitant agent (2011 $\mathrm{U} \mathrm{mg}^{-1}$ versus $1912 \mathrm{U} \mathrm{mg}^{-1}$ predicted by the models), ethanol was chosen as precipitant agent for peroxidase CLEAs preparation. Optimal conditions using ethanol enabled a recovered activity of $77 \%$.
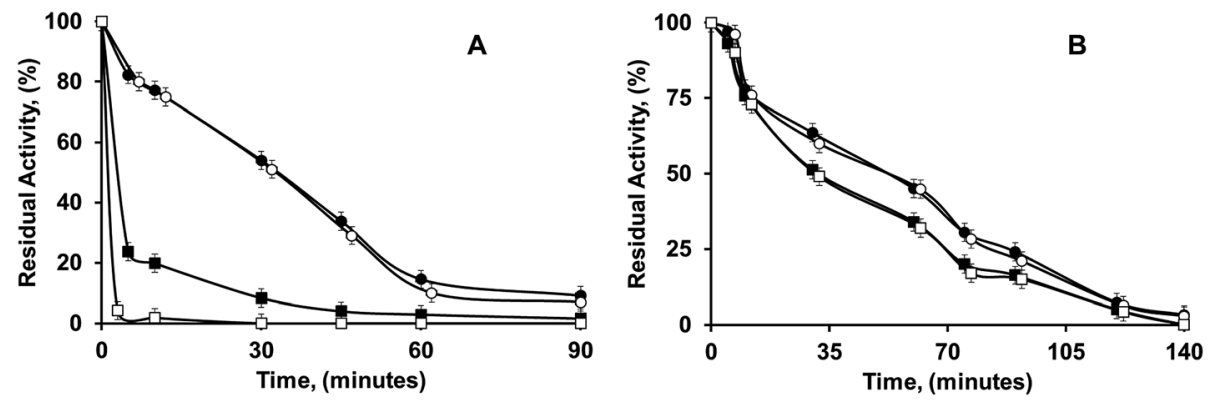

Fig. 2 Thermal stability of the different peroxidase preparations under different conditions. Other specifications are described in Section 2. Panel A: thermal inactivation at $65^{\circ} \mathrm{C}$ and $\mathrm{pH}$ 3. Panel B: thermal inactivation at $90{ }^{\circ} \mathrm{C}$ and $\mathrm{pH}$ 7. Full circles: $1.2 \mathrm{U}$ of $\mathrm{CLEAs}$, empty circles: $0.6 \mathrm{U}$ of CLEAs, full squares: $1.2 \cup$ of RPTP, empty squares: $0.6 \cup$ of RPTP. 

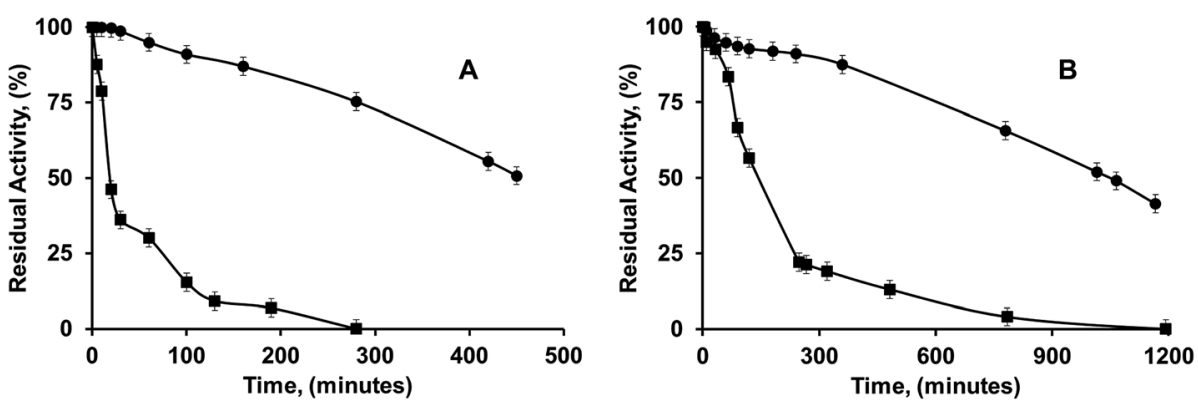

Fig. 3 Hydrogen peroxide stability of the different peroxidase preparations under different conditions. Other specifications are described in Section 2. Panel A: inactivation at $\mathrm{pH}$ 3. Panel B: inactivation at $\mathrm{pH}$ 7. Circles: CLEAs, squares: RPTP.

\subsection{Characterization of the peroxidase CLEAs compared to the free enzyme}

3.2.1. Activity/pH profile of the free and peroxidase CLEAs. Fig. 1 shows the activity/pH profile of both samples of peroxidase. The free enzyme has a clear maximum activity at $\mathrm{pH} 7$, with a rapid activity drop at basic or acidic $\mathrm{pH}$ values. The CLEA has maximum activity at $\mathrm{pH} 6$, and the activity drop at alkaline $\mathrm{pH}$ values is similar to that experimented by the free enzyme, however at acidic $\mathrm{pH}$ value the enzyme retained much higher activity. At pH 3, the immobilized peroxidase exhibited around $40 \%$ of the maximum activity, while the free enzyme is almost fully inactive. This way, the range of likely $\mathrm{pH}$ values to use this enzyme is greatly increased after immobilization.

3.2.2. Stability at different $\mathbf{p H}$ values. This enzyme has been reported to be very thermostable. ${ }^{10}$ It has been proposed that its very high themostability may be related to the dimeric nature of the enzyme. ${ }^{11,12}$ On the other hand, it has been reported that in certain cases, the inactivation of multimeric enzymes starts via subunit dissociation ${ }^{\mathbf{1 4}}$ and this may be a problem for the industrial use of diluted samples of this kind of enzymes. Fig. 2a shows the inactivation course of free enzyme and CLEA at two different concentrations, at $\mathrm{pH} 7$ and $90{ }^{\circ} \mathrm{C}$.

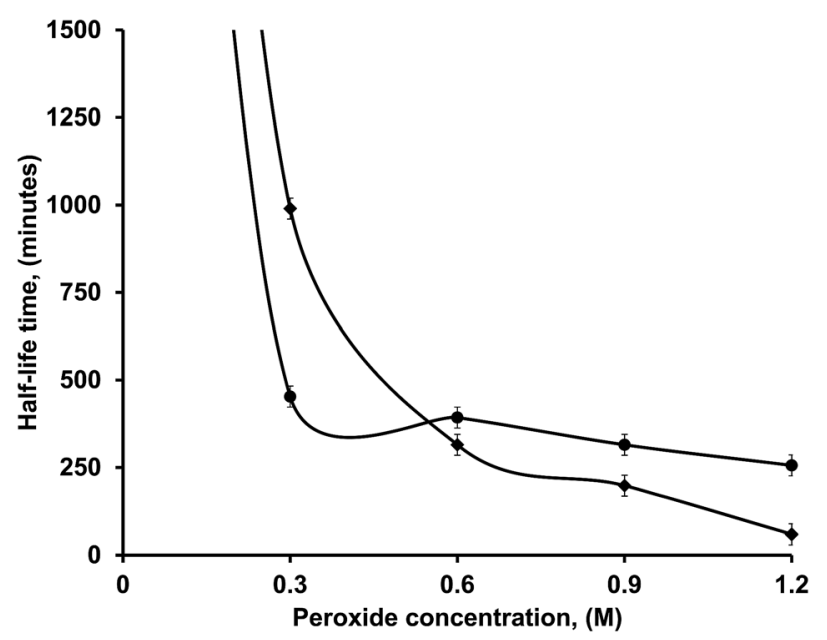

Fig. 4 Effect of hydrogen peroxide concentration on the half live of the immobilized enzyme. Other specifications are described in Section 2. Circles: $\mathrm{pH}$ 3, rhombus: $\mathrm{pH} 6$.
The figure confirms the very high stability of the enzyme (that remained fully active after $3 \mathrm{~h}$ at $70{ }^{\circ} \mathrm{C}$, results not shown). The half-lives of both CLEA and free enzyme (50 $\mathrm{min}$ ) are very similar and did not significantly depend on the concentration of the enzyme, suggesting that under these conditions the enzyme is not dissociated before becoming inactivated. However, at $\mathrm{pH}$ 3 and $65{ }^{\circ} \mathrm{C}$ the situation is fairly different (Fig. 2b). First, CLEA preparation is much more stable than the free enzyme. Second, the free enzyme is less stable if the concentration decreased. This suggested that at $\mathrm{pH} 3$, the first step of the inactivation of the free enzyme is the enzyme subunit dissociation, and the CLEA immobilization is able to fully prevent this dissociation because it involves all enzyme subunits. ${ }^{21}$

3.2.3. Stability in the presence of hydrogen peroxide. Hydrogen peroxide is a reagent that may rapidly inactivate enzymes by chemical modification of different groups, but in this case it is also a substrate of the enzyme. ${ }^{6}$ Therefore, the enzyme needs to be resistant to this reagent to be used at industrial level, or may be used in more sophisticated reactor configurations or generating the hydrogen peroxide in situ (e.g., using an oxidase). ${ }^{7}$ Fig. 3 shows that the free peroxidase is very unstable at $300 \mathrm{mM}$ hydrogen peroxide and $25{ }^{\circ} \mathrm{C}$ at both $\mathrm{pH} 7$ and 3 (half-lives of 130 minutes at $\mathrm{pH} 7$ and 20 minutes at $\mathrm{pH} 3$ ), the immobilization using CLEA technology allows to greatly improve enzyme stability (half-lives of 1060 and 450 minutes at $\mathrm{pH} 7$ and 3, respectively). The stabilization is higher at $\mathrm{pH} 3$ (perhaps by preventing the dissociation of the enzyme subunits,

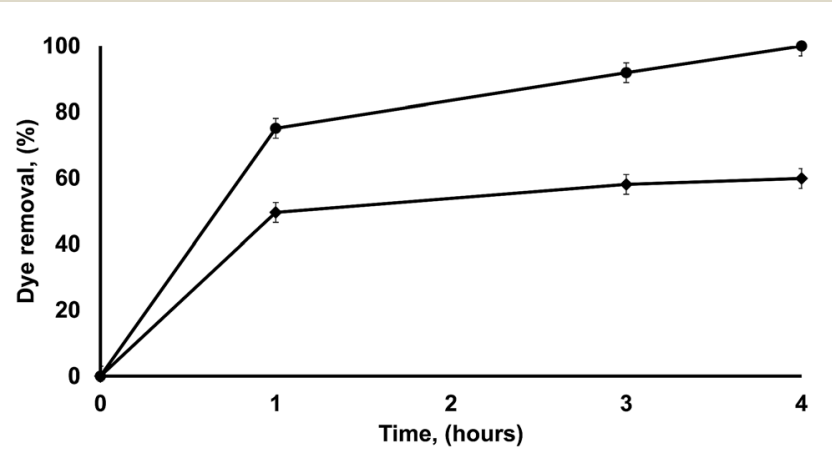

Fig. 5 Effect of $\mathrm{H}_{2} \mathrm{O}_{2}$ concentration on methyl orange destruction with the immobilized enzyme at $\mathrm{pH}$ 6. Other specifications are described in Section 2. Circles: 225 mM, rhombus: 5 mM. 


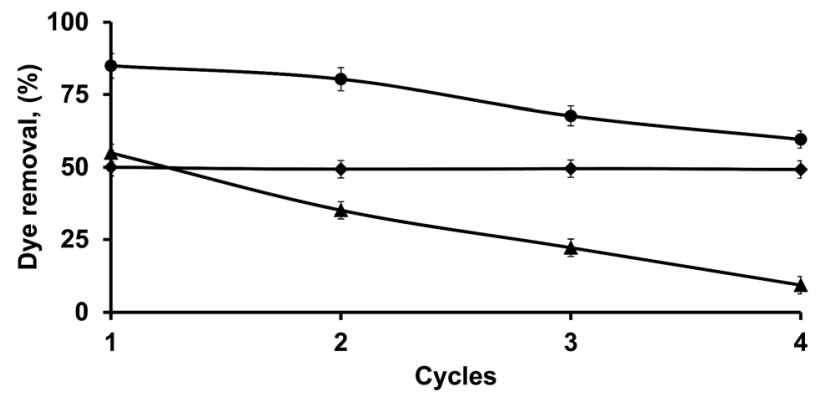

Fig. 6 Reusability of CLEAs on methyl orange destruction. Other specifications are described in Section 2. Circles: $225 \mathrm{mM}$ at $\mathrm{pH}$ 6, rhombus: $5 \mathrm{mM}$ at $\mathrm{pH}$ 6, triangles: $225 \mathrm{mM}$ at $\mathrm{pH} 3$.

that may expose more enzyme surface to the deleterious action of the $\mathrm{H}_{2} \mathrm{O}_{2}$ ), but the CLEA is still more stable at $\mathrm{pH} 7$ than at $\mathrm{pH}$ 3. Fig. 4 shows the effect of $\mathrm{H}_{2} \mathrm{O}_{2}$ concentration on the half live of the immobilized enzyme. While at concentrations under $10 \mathrm{mM} \mathrm{H}_{2} \mathrm{O}_{2}$ the enzyme remained fully active after $10 \mathrm{~h}$, at $300 \mathrm{mM}$ the half-live is only $7.5 \mathrm{~h}$ and using $1.2 \mathrm{M}$ is just over $4 \mathrm{~h}$.

\subsection{Operational stability}

Fig. 5 shows the peroxidase-CLEA catalyzed destruction of $45 \mu \mathrm{M}$ methyl orange using 5 or $225 \mathrm{mM}$ hydrogen peroxide at $\mathrm{pH}$ 6. Using $225 \mathrm{mM}$ hydrogen peroxide, the conversion is near $100 \%$ after $4 \mathrm{~h}$. Using $5 \mathrm{mM}$ hydrogen peroxide, conversion is around $50 \%$ after $1 \mathrm{~h}$, and hardly increased if the time is prolonged to $4 \mathrm{~h}$. To measure the operation stability under both conditions, we decided to use as $100 \%$ the decoloration values obtained at $3 \mathrm{~h}\left(225 \mathrm{mM} \mathrm{H}_{2} \mathrm{O}_{2}\right)$ or $1 \mathrm{~h}\left(5 \mathrm{mM} \mathrm{H}_{2} \mathrm{O}_{2}\right)$, but using cycles of $4 \mathrm{~h}$ (that is, after $4 \mathrm{~h}$ the enzyme was recovered and reused) in both cases to have comparable reaction cycle-time (Fig. 6). While using $225 \mathrm{mM} \mathrm{H}_{2} \mathrm{O}_{2}$ at $\mathrm{pH} 6$ the conversion at $3 \mathrm{~h}$ were reduced from $85 \%$ to $60 \%$ in 4 cycles, using $5 \mathrm{mM} \mathrm{H}_{2} \mathrm{O}_{2}$ the enzyme remained fully active after the 4 cycles (Fig. 6). At pH 3 and using $225 \mathrm{mM} \mathrm{H}_{2} \mathrm{O}_{2}$, conditions where the free enzyme was fully inactive (Fig. 1) and with low stability (Fig. 2), the immobilized enzyme suffered a progressive decrease in enzyme activity after each cycle, going from a elimination of $55 \%$ in the first cycle (significantly lower than at $\mathrm{pH} 6$, according to the lower activity at this $\mathrm{pH}$ value), to only a $10 \%$ in the fourth cycle. However, it is remarkable that we have been able to prepare a biocatalyst that may be used several cycles under conditions where the free enzyme is fully inactive.

\section{Conclusions}

This paper details the optimization of the preparation of CLEAs of the dimeric peroxidase from Roystonea regia. The final recovered activity was $77 \%$ of the initial one, a very high value considering the diffusion problem of these preparations and the difficulty in fully recovering all the solid. These CLEAs have permitted to fully prevent the enzyme dissociation that occurred at $\mathrm{pH} 3$ and high temperature. Thus, while at $\mathrm{pH} 7$ the RPTP stability observed after the CLEA preparation is only marginally higher than that of the free enzyme, at $\mathrm{pH} 3$ the stabilization achieved is quite significant and depended on the concentration of the free enzyme (because this decreases when the enzyme concentration does). Nevertheless, the stability of the peroxidase-CLEAs remains much higher at $\mathrm{pH} 7$ than at pH 3.

The free RTPT stability in the presence of low concentrations of hydrogen peroxide is very good, but if we used moderate hydrogen peroxide concentrations, the stability is not so good. The immobilization via the optimized CLEA protocol provide a significant stabilization in the presence of this reagent, but still the half live is relatively low for industrial purposes.

Thus, the RPTP-CLEA could be reused for 4 cycles without any loss of activity at pH 6 and using $5 \mathrm{mM}$ of hydrogen peroxide, but removing only $50 \%$ of the color generated by $45 \mu \mathrm{M}$ of methyl orange. Use of higher concentrations of hydrogen peroxide permitted a full color removal, but the enzyme decreased the activity in a significant way each reaction cycle. Thus, further efforts to have more stable RPTP biocatalysts seem convenient to increase its prospects as industrial biocatalyst.

\section{Acknowledgements}

We gratefully recognize the support from the MINECO of Spanish Government, CTQ2013-41507-R and project 1391 from the Department of research and extension of the Health facultyUIS. The predoctoral fellowship for Ms Rueda (Colciencia, Colombian Government). The help and comments from Dr Ángel Berenguer (Instituto de Materiales, Universidad de Alicante) are kindly acknowledged.

\section{References}

1 M. P. J. Van Deurzen, F. Van Rantwijk and R. A. Sheldon, Tetrahedron, 1997, 53, 13183-13220.

2 S. Colonna, N. Gaggero, C. Richelmi and P. Pasta, Trends Biotechnol., 1999, 17, 163-168.

3 W. Adam, M. Lazarus, C. R. Saha-Möller, O. Weichold, U. Hoch, D. Häring and P. Schreier, Adv. Biochem. Eng./ Biotechnol., 1999, 63, 73-108.

4 M. Hamid and R. Khalil ur, Food Chem., 2009, 115, 11771186.

5 Q. Husain, Rev. Environ. Sci. Biotechnol., 2010, 9, 117-140.

6 K. Hernandez, A. Berenguer-Murcia, R. C. Rodrigues and R. Fernandez-Lafuente, Curr. Org. Chem., 2012, 16, 26522672.

7 J. Rocha-Martin, S. Velasco-Lozano, J. M. Guisán and F. López-Gallego, Green Chem., 2014, 16, 303-311.

8 D. Jung, C. Streb and M. Hartmann, Microporous Mesoporous Mater., 2008, 113, 523-529.

9 H. Uyama, H. Kurioka and S. Kobayashi, Polym. J. (Tokyo, Jpn.), 1997, 29, 190-192.

10 I. Y. Sakharov, M. K. Vesgac B, I. Y. Galaev, I. V. Sakharova and O. Y. Pletjushkina, Plant Sci. (Amsterdam, Neth.), 2001, 161, 853-860.

11 L. Watanabe, P. R. de Moura, L. Bleicher, A. S. Nascimento, L. S. Zamorano, J. J. Calvete, L. Sanz, A. Pérez, S. Bursakov, 
M. G. Roig, V. L. Shnyrov and I. Polikarpov, J. Struct. Biol., 2010, 169, 226-242.

12 L. Watanabe, A. S. Nascimento, L. S. Zamorano, V. L. Shnyrov and I. Polikarpov, Acta Crystallogr., Sect. F: Struct. Biol. Cryst. Commun., 2007, 63, 780-783.

13 L. S. Zamorano, D. G. Pina, J. B. Arellano, S. A. Bursakov, A. P. Zhadan, J. J. Calvete, L. Sanz, P. R. Nielsen, E. Villar, O. Gavel, M. G. Roig, L. Watanabe, I. Polikarpov and V. L. Shnyrov, Biochimie, 2008, 90, 1737-1749.

14 R. Fernandez-Lafuente, Enzyme Microb. Technol., 2009, 45, 405-418.

15 I. S. Alpeeva and I. Y. Sakharov, Appl. Biochem. Microbiol., 2007, 43, 25-28.

16 Y. M. Mazhugo, A. V. Caramyshev, S. V. Shleev, I. Y. Sakharov and A. I. Yaropolov, Appl. Biochem. Microbiol., 2005, 41, 247250.

17 R. A. Sheldon, Org. Process Res. Dev., 2011, 15, 213-223.

18 R. A. Sheldon, Biochem. Soc. Trans., 2007, 35, 1583-1587.

19 R. Schoevaart, M. W. Wolbers, M. Golubovic, M. Ottens, A. P. G. Kieboom, F. Van Rantwijk, L. A. M. Van Der Wielen and R. A. Sheldon, Biotechnol. Bioeng., 2004, 87, 754-762.
20 L. Cao, F. Van Rantwijk and R. A. Sheldon, Org. Lett., 2000, 2, 1361-1364.

21 L. Wilson, L. Betancor, G. Fernández-Lorente, M. Fuentes, A. Hidalgo, J. M. Guisán, B. C. C. Pessela and R. Fernández-Lafuente, Biomacromolecules, 2004, 5, 814-817.

22 C. Garcia-Galan, A. Berenguer-Murcia, R. FernandezLafuente and R. C. Rodrigues, Adv. Synth. Catal., 2011, 353, 2885-2904.

23 S. Talekar, A. Joshi, G. Joshi, P. Kamat, R. Haripurkar and S. Kambale, RSC Adv., 2013, 3, 12485-12511.

24 S. J. Kalil, F. Maugeri and M. I. Rodrigues, Process Biochem., 2000, 35, 539-550.

25 J. Cruz, O. Barbosa, R. C. Rodrigues, R. Fernandez-Lafuente, R. Torres and C. Ortiz, J. Mol. Catal. B: Enzym., 2012, 80, 7-14. 26 M. M. Bradford, Anal. Biochem., 1976, 72, 248-254.

27 O. Barbosa, C. Ortiz, A. Berenguer-Murcia, R. Torres, R. C. Rodrigues and R. Fernandez-Lafuente, RSC Adv., 2014, 4, 1583-1600.

28 J.-i. Kawahara, K. Ishikawa, T. Uchimaru and H. Takaya, in Polymer Modification, ed. G. Swift, C. Carraher Jr and C. Bowman, Springer, US, 1997, pp. 119-131.

29 R. C. Rodrigues, C. Ortiz, A. Berenguer-Murcia, R. Torres and R. Fernandez-Lafuente, Chem. Soc. Rev., 2013, 45, 6290-6307. 